慶應義塾大学学術情報リポジトリ

Keio Associated Repository of Academic resouces

\begin{tabular}{|c|l|}
\hline Title & Studies of body fluids with optical fiber sensors \\
\hline Sub Title & \\
\hline Author & $\begin{array}{l}\text { 高橋, 千佳子(Takahashi, Chikako) } \\
\text { 金子, 明子(Kaneko, Akiko) } \\
\text { 小股, 泰子(Komata, Yasuko) } \\
\text { 横山, 祥子(Yokoyama, Shoko) } \\
\text { 藤江, 忠雄(Fujie, Tadao) }\end{array}$ \\
\hline Publisher & 共立薬科大学 \\
\hline Publication year & 1993 \\
\hline Jtitle & $\begin{array}{l}\text { 共立薬科大学研究年報 (The annual report of the Kyoritsu College of } \\
\text { Pharmacy). No.38 (1993. ),p.86-86 }\end{array}$ \\
\hline JaLC DOI & \\
\hline Abstract & \\
\hline Notes & 抄録 \\
\hline Genre & Technical Report \\
\hline URL & https://koara.lib.keio.ac.jp/xoonips/modules/xoonips/detail.php?koara_id=AN00062898-0000003 \\
\hline & $8-0086$ \\
\hline
\end{tabular}

慶應義塾大学学術情報リポジトリ(KOARA)に掲載されているコンテンツの著作権は、それぞれの著作者、学会または出版社/発行者に帰属し、その権利は著作権法によって 保護されています。引用にあたっては、著作権法を遵守してご利用ください。

The copyrights of content available on the KeiO Associated Repository of Academic resources (KOARA) belong to the respective authors, academic societies, or publishers/issuers, and these rights are protected by the Japanese Copyright Act. When quoting the content, please follow the Japanese copyright act. 


\title{
Studies of Body Fluids with Optical Fiber Sensors*
}

\author{
Chikako TaKahashi, Akiko Kaneko, Yasuko Komata,
}

Shoko Yokoyama and Tadao FujIE

高橋千佳子, 金子明子, 小股泰子, 横山祥子, 藤江忠雄

For monitoring of various kinds of constituents in biological fluids, many different types of sensors have been developed. Most of them have been based on the ability of materials immobilized directly onto electrodes to react specifically with an analyte. In this study we have performed a fundamental study of a glucose sensor utilized an optical fiber based on a spectroscopic detection system. We prepared two types of the membranes. One was the membrane for a $\mathrm{pH}$ sensor. The others gas the membrane for a glucose sensor containing glucose oxidase and bromothymol blue. The sensor responded to $\mathrm{pH}$ change due to the gluconic acid resulting from glucose.

From the results of the two types of sensor, it is considered that the optical fiber sensors are effective for biochemical analysis of body fluids. There is a possibility that the optical fiber sensor may be applicable to the analytical method in vivo.

* 本報告は Sensors and Acutuators B, 13-14.756-757（1993）に発表。 